\title{
LIN28B Gene
}

National Cancer Institute

\section{Source}

National Cancer Institute. LIN28B Gene. NCI Thesaurus. Code C101416.

This gene plays a role in the suppression of miRNA processing. 